\title{
1 A new pterosaur from Skye, Scotland and the early diversification of flying
}

2 reptiles

3 Elizabeth Martin-Silverstone ${ }^{1^{*}}$, David M. Unwinn ${ }^{2}$, Andrew R. Cuff ${ }^{3}$, Emily E. Brown ${ }^{4,5}$,

4 Lu Allington-Jones ${ }^{6}$, and Paul M. Barrett ${ }^{4}$

$5{ }^{1}$ School of Earth Sciences, University of Bristol, Life Sciences Building, 24 Tyndall

6 Avenue, Bristol, BS8 1TQ, UK

72 Museum Studies, University of Leicester, Museum Studies Building, 19 University

8 Road, Leicester LE1 7RF, UK

$9{ }^{3}$ Human Anatomy Resource Centre, University of Liverpool, Sherrington Building,

10 Ashton Street, Liverpool, L69 3GE, UK

$11{ }^{4}$ Department of Earth Sciences, Natural History Museum, Cromwell Road, London

12 SW7 5BD, UK

$13{ }^{5}$ School of Geography, Earth \& Environmental Sciences, University of Birmingham,

14 Edgbaston, Birmingham, B15 2TT, UK

$15{ }^{6}$ Conservation Centre, Natural History Museum, Cromwell Road, London SW7 5BD, 16 UK 


\section{Abstract}

23 The Middle Jurassic was a critical time in pterosaur evolution, witnessing the

24 inception of major morphological innovations that underpinned successive radiations

25 by rhamphorhynchids, basal monofenestratans and pterodactyloids. Frustratingly,

26 this interval is particularly sparsely sampled, with a record consisting almost

27 exclusively of isolated fragmentary remains. Here, we describe new material from

28 the Bathonian-aged Kilmaluag Formation of Skye, Scotland, which helps to close this

29 gap. REDACTED (gen. et sp. nov.) is based on a three-dimensionally preserved

30 partial skeleton, which represents the first associated Middle Jurassic pterosaur.

31 REDACTED is one of the first pterosaurs to be fully digitally prepared and $\mu \mathrm{CT}$

32 scanning reveals multiple elements of the skeleton that remain fully embedded within

33 the matrix, which are otherwise inaccessible. Novel anatomical features of this new

34 Middle Jurassic pterosaur help to confirm the existence of the controversial clade

35 Darwinoptera, greatly clarifying our understanding of Jurassic pterosaur evolution. 


\section{Introduction}

The earliest known pterosaur fossils come from the Late Triassic, but the group persisted until the $\mathrm{K}-\mathrm{Pg}$ extinction [1,2]. Pterosaurs are typically divided into three large groups: the basal, polyphyletic 'rhamphorhynchoids', which existed from the Norian; the derived pterodactyloids, which appeared in the Late Jurassic; and the basal monofenestratans that intervened between them from the Middle-Late Jurassic. Basal monofenestratans have been suggested to be a transitional, polyphyletic group leading to pterodactyloids [3,4] but the monophyly and relationships of these taxa (many referred to Wukongopteridae) are controversial $[5,6]$.

Pterosaurs are known from every continent [2,7] and experienced two large peaks in species-richness: in the Early-'middle' Cretaceous and latest Cretaceous $[8,9]$. However, their distribution is highly affected by the 'Lagerstätten effect' and other forms of sampling bias [8-10]. The majority of pterosaur fossils have been collected from Konservat-Lagerstätten (deposits with exceptional preservation) and it has been demonstrated that times and places of high diversity track exceptional preservation potential $[9,10]$. For example, the Late Jurassic pterosaur record is dominated by Konservat-Lagerstätten such as the Solnhofen Limestones of Germany and the Daohugou Beds of China, which both yield nearly complete specimens, often with associated soft tissues $[1,11,12]$. Both of these faunas include pterodactyloids and basal non-pterodactyloids. The younger Early-'middle'

58 Cretaceous is best known for areas such as the Konzentrat-Lagerstätten of the Cambridge Greensand (UK) [13], where hundreds of disarticulated and fragmentary pterodactyloid pterosaur bones have been found and several Konservat- 
62 Formations of Brazil, where complete skeletons of pterodactyloids have been

63

64

65

66

67

68

69 recovered frequently $[1,11]$. As a result, almost all of our knowledge of pterosaur evolutionary history is based on material from a handful of sites with restricted spatiotemporal coverage.

The Middle Jurassic pterosaur fossil record is exceptionally poor. The Stonesfield Slate (UK) provides the best example but, although abundant pterosaur material has been found, all of it is disarticulated, isolated and often fragmentary, making estimates of diversity and anatomical description difficult [15]. Recent studies have proposed that other potentially Middle Jurassic pterosaur-bearing localities, such as the Tiaojishan Formation (China), are Late Jurassic instead [16].

The scarcity of Middle Jurassic pterosaur-bearing formations and diagnosable taxa from this period are problematic when attempting to understand early pterosaur evolution. Pterosaur phylogenies suggest that Monofenestrata and Pterodactyloidea both diverged during this interval, but direct evidence for the timing of these events remains elusive. For these reasons, any new Middle Jurassic pterosaur material, especially significantly complete skeletons, are important in constraining the spatiotemporal context and evolutionary mode of the pterosaur radiation. Here, we describe a new three-dimensionally preserved partial skeleton from the Middle Jurassic (Bathonian: 168-166 million years ago) of the Isle of Skye, Scotland, which is the first associated pterosaur discovered in Scotland and the most complete Middle Jurassic pterosaur found to date.

\section{Material and Methods}

Due to the fragility of the bones and the hardness of the surrounding matrix, traditional mechanical preparation was difficult and the specimen was partially 
87 prepared using acetic acid (see Supplementary Material). In order to visualize more

details of the specimen, including elements that remain fully encased in matrix, microcomputed tomography $(\mu \mathrm{CT})$ scanning of the specimen was performed at the University of Bristol X-Ray Tomography Facility and segmented using Avizo Lite 9.5 (see Supplementary Material for details).

The specimen was scored into a new pterosaur data matrix, consisting of 65 taxa and 137 characters, and a phylogenetic analysis was performed in TNT (see Supplementary Material for more details).

\section{Systematic Palaeontology}

PTEROSAURIA Kaup, 1834

MONOFENESTRATA Lü et al., 2010

DARWINOPTERA Andres et al., 2014

REDACTED gen. et sp. nov.

Holotype. NHMUK PV R37110, an associated partial skeleton consisting of several vertebrae, a sternum with cristospine, a partial right pelvis, a complete right scapulocoracoid, a partial left ulna, a proximal syncarpal, a distal syncarpal, two metacarpal IVs, several digit IV phalanx fragments, a proximal femur fragment, and numerous other long bone and unidentifiable fragments (Fig. 1).

Type locality and horizon. The holotype was found in 2006 by a team from the Natural History Museum (led by PMB), at Cladach a'Ghlinne, north of Elgol, Isle of Skye, Scotland, UK, and comes from the Bathonian-aged Kilmaluag Formation (see Supplementary Fig. 1 and [17-19]). 


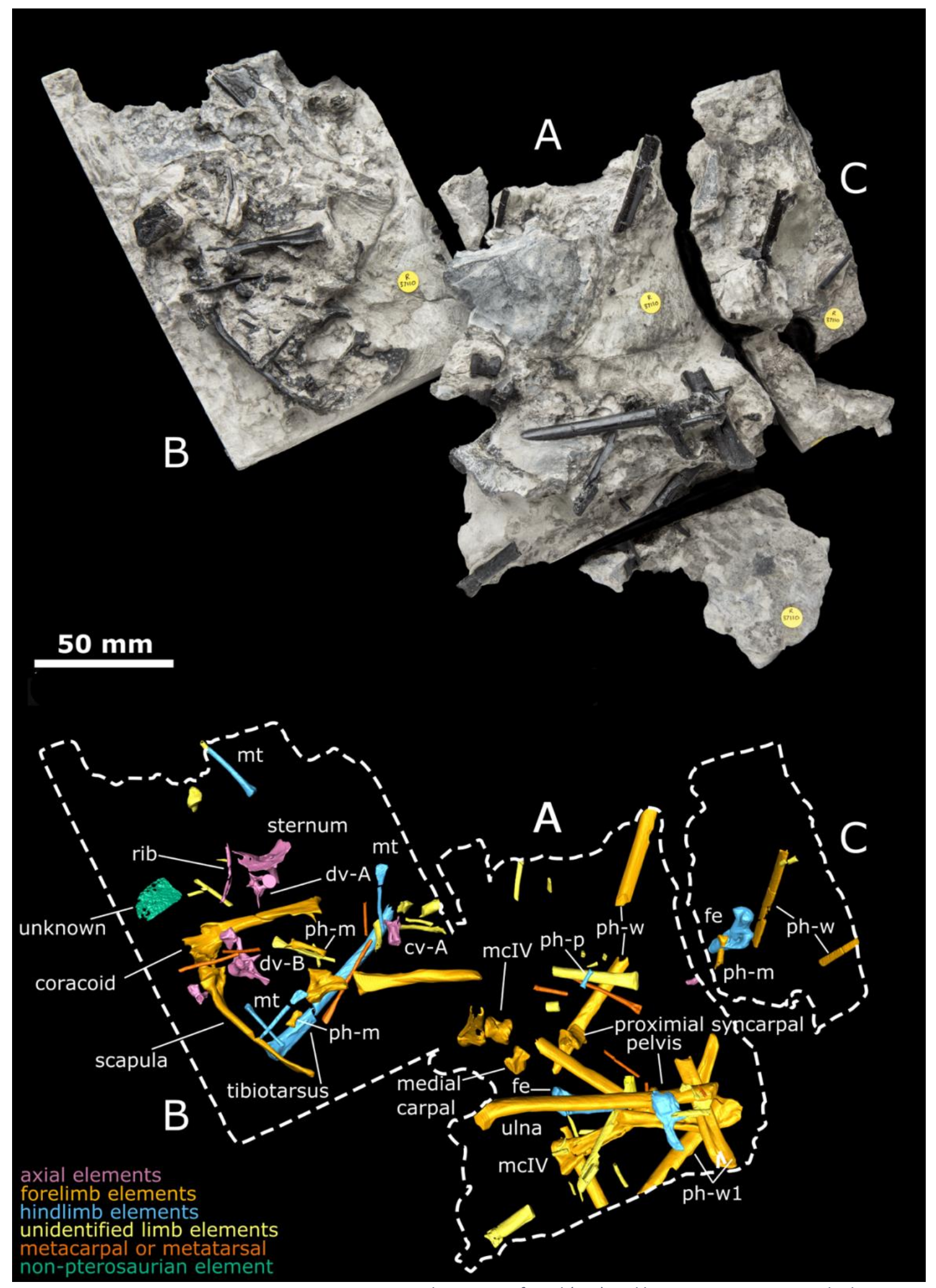
(bottom). Letters indicate the blocks as discussed in the text. Abbreviations: cv/dv, cervical/dorsal vertebra; fe, femur; $m$, 

darwinopterans by the presence of sternocoracoid articulations lying anterior and posterior to one another, and with a cristospine that is short and deep. REDACTED is further diagnosed by a single autapomorphy, the uniquely shaped end of the coracoid with an articular surface for sternal articulation.

\section{Results}

A more detailed description can be found in the Supplementary Material, but REDACTED is undistorted and complete. The scapula and coracoid are preserved as two separate yet articulated elements, but it is unclear if they were unfused or broken. The glenoid is located chiefly on the scapula, but partially on the coracoid. The scapula and coracoid are similar in length, with the coracoid being shorter (Table S1), and the distal end of the scapula is expanded and bulbous. A prominent flange is present on the distal coracoid, likely for the attachment of the $m$. sternocoracoideus. The sternum is incomplete, with just the cristospine and the most anterior portion of the sternal plate present. The cristospine is short and potential pneumatic foramina are present on the dorsal (internal) side of the base of the cristospine, where the sternal plate begins.

REDACTED falls out as a monofenestratan darwinopteran and sister taxon of Kryptodrakon progenitor. Darwinoptera is supported by five characters, including two diagnostic characters of Darwinoptera: phalanx two of pedal digit $\mathrm{V}$ with distinctive angular flexure at midlength, such that the distal half of the phalanx lies at $40-45^{\circ}$ to the proximal half; and the scapula distal end is bulbous in shape. The other three features are synapomorphic reversals: ulna/tibia ratio $0.9-1.2$; unguals of manus and 


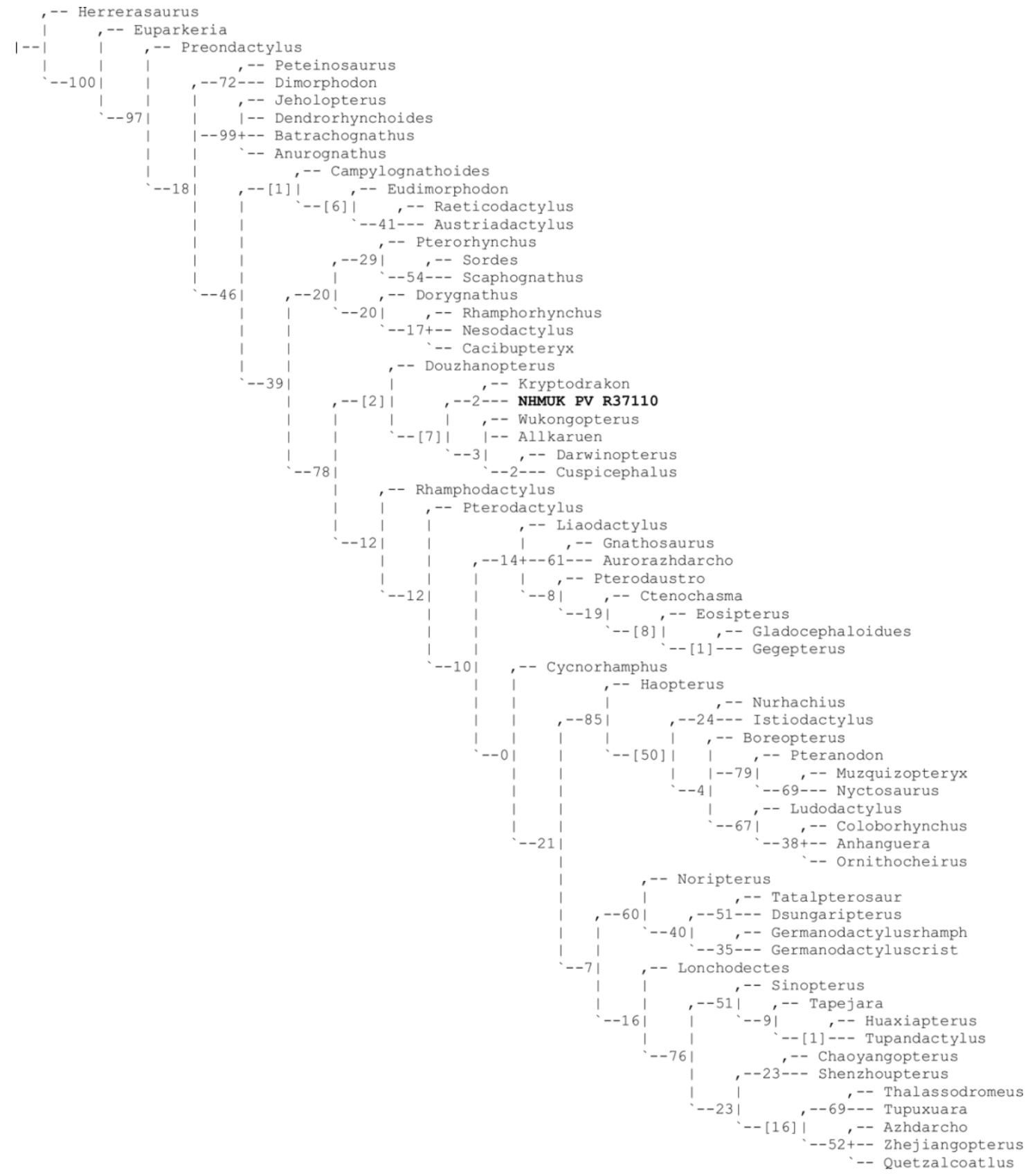

5. Discussion

147 REDACTED from the Middle Jurassic of Skye, Scotland is important for several

148 reasons. It provides new insights into key anatomical features of the shoulder girdle, 
150 Darwinoptera, which is the sister group to Pterodactyloidea. It is also the most

151 complete undisputed Middle Jurassic pterosaur and its age and phylogenetic

152 position have a major impact on our knowledge of pterosaur evolutionary history. So-

153 called 'transitional' pterosaurs, exhibiting a mosaic of features found in the long-

154 tailed 'rhamphorhynchoids' and short-tailed pterodactyloids, were first recognised with the descriptions of Darwinopterus [3] and Wukongopterus [5], which occupied varied positions in the pterosaur tree. Together with pterodactyloids, these 'transitional' taxa form the clade Monofenestrata [3]. These discoveries led to the proposal of modular evolution for pterosaurs, with different areas of the skeleton evolving at different times and rates [3]. Wukongopterus was initially regarded as a very basal pterosaur [5] and its position has been difficult to constrain [6], and several other pterosaurs have been regarded as close relatives (included in Wukongopteridae [4]). Some more recent studies have recovered a monophyletic Wukongopteridae and Darwinoptera (Wukongopteridae + Pterorhynchus wellnhoferi) as basal monofenestratans [20]. Jurassic/earliest Middle Jurassic pterosaur Allkaruen koi (previously thought to be a sister taxon to Monofenestra [21]) and the Middle-Late Jurassic Kryptodrakon progenitor (formerly the oldest known pterodactyloid [20]). Darwinoptera also includes taxa previously described as 'wukongopterids' (although they do not form a monophyletic 'wukongopterid' clade), including Douzhanopterus [4], Cuspicephalus [22], Darwinopterus [3] and Wukongopterus [5]. also results in an earlier divergence of Monofenestra and Darwinoptera than thought previously. Formerly, the earliest confirmed monofenestratans were all from the 
175 Tiaojishan Formation of China $[3,4,23,24]$. Although the exact age of the Tiaojishan

176 Formation is debated, it appears to be latest Middle Jurassic (Callovian) or Late

177 Jurassic (Oxfordian) in age, between 164-155 Ma [25-29]. Slightly younger than

178 these are several Late Jurassic European non-pterodactyloid monofenestratans

179 (Cuspicephalus scarfi, Normannognathus wellnhoferi [22], and the un-named

180 'Painten pro-pterodactyloid' [30]). Earlier monofenestratan records from the

181 Bathonian Stonesfield Slate [31] are either incorrect or too fragmentary to include in

182 phylogenetic analyses [15,20]. Our results therefore recalibrate the origin of

183 Monofenestrata, pulling this event back to the early Middle Jurassic, approximately

184 8-10 million years earlier than previous estimates.

The identification of these early monofenestratans also raises questions about when and where Monofenestrata and Pterodactyloidea evolved, highlighting the patchiness of the pterosaur record at this important time in their evolution. Recovery of Kryptodrakon progenitor (Callovian: $162.7 \mathrm{Ma}$ ) as a darwinopteran, rather than the earliest pterodactyloid [20], restricts pterodactyloideans to the Late Jurassic onward, but extends the range of darwinopterans from the latest Early Jurassic to the Late Jurassic, and possibly into the Early Cretaceous by including Wukongpterus and Kunpengopterus within a monophyletic Darwinoptera. However, most darwinopterans are known from the latest Middle-Late Jurassic of China, leaving important gaps in the Early Jurassic. The earliest-known darwinopteran is Gondwanan [21], but our understanding of early pterosaur biogeography is limited [7].

This new tree topology also challenges our understanding of pterosaur evolution. When Darwinopterus was discovered, it was hailed as a transitional fossil, leading to the suggestion that pterosaurs underwent modular evolution with two 
phases: first, from the basal 'rhamphorhynchoid' pterosaurs to basal monofenestratans; with the second phase to pterodactyloids [3]. This was thought to explain the combination of features seen in Darwinopterus, which includes some primitive characters, such as a short wing metacarpal and a long tail, in combination with more derived features, such as a single nasoantorbital fenestra and longer skull. However, a monophyletic Darwinoptera that is the sister-taxon to Pterodactyloidea, combined with an increased number of basal monofenestratans with varying character combinations, suggests that pterosaur evolution may not have been modular, but more of a mosaic with different species evolving features at different times. Previous studies suggested that pterosaur evolution may have followed a mosaic pattern on a finer scale within anatomical units (e.g. the neurocranium and braincase) while retaining modular evolution at the level of major anatomical units (e.g. skull vs. body) [4,21]. However, we suggest that even at a gross anatomical level, modular evolution may not be tenable.

\section{Conclusions}

REDACTED is the first pterosaur to be named from Scotland and the most complete

217 pterosaur to be found in the UK since Mary Anning discovered Dimorphodon macronyx in the early 1800s [32]. Its Middle Jurassic age, phylogenetic position and status as one of the most complete darwinopterans further elevate its significance, as it helps to shed light on when and how Monofenestrata, Darwinoptera and Pterodactyloidea evolved. Darwinoptera is shown to be a clade, not a grade, and to

222 include pterosaurs from South America, Europe and Asia, demonstrating that it was diverse, widespread and persisted for at least 30 million years. Additional work

224 remains to be carried out on Middle Jurassic pterosaurs, especially those from the 
225 UK. Burgeoning new vertebrate fossil finds from the late Early-Middle Jurassic of

226 Scotland [19], especially the Isle of Skye, including dinosaurs [17,33,34],

227 crocodylomorphs [34], ichthyosaurs [35], turtles [18], and mammals [36], suggest

228 that this area has high potential for revealing even more critical information on

229 Middle Jurassic faunal evolution.

230

231 Acknowledgements

232 We thank S. E. Evans for introducing PMB to the locality, J. Anquetin, S. Feerick and

233 S. Moore-Fay for assistance with fieldwork, and Scottish Nature and the John Muir

234 Trust for permissions and access to the locality. The Natural History Museum and

235 the Palaeontographical Society provided funding. We thank M. Day for access to the

236 specimen, T. Davies for CT scanning, D. Sykes for an early exploratory scan and D.

237 Martill, M. O’Sullivan, and M. Witton for discussions. 


\section{References}

240 1. Witton MP. 2013 Pterosaurs: natural history, evolution, anatomy. Princeton, USA: Princeton University Press.

2. Barrett PM, Butler RJ, Edwards NP, Milner AR. 2008 Pterosaur distribution in time and space: an atlas. Zitteliana B28, 61-107.

3. Lü J, Unwin DM, Jin X, Liu Y, Ji Q. 2010 Evidence for modular evolution in a long-tailed pterosaur with a pterodactyloid skull. Proc. R. Soc. B Biol. Sci. 277, 383-389.

4. Wang X, Jiang S, Zhang J, Cheng X, Yu X, Li Y, Wei G, Wang X. 2017 New evidence from China for the nature of the pterosaur evolutionary transition. Sci. Rep. 7, 42763. (doi:10.1038/srep42763)

5. Wang X, Kellner AWA, Jiang S, Meng X. 2009 An unusual long-tailed Bras. Cienc. 81, 793-812.

6. Wang X, Kellner AWA, Jiang S, Cheng X, Meng X, Rodrigues T. 2010 New long-tailed pterosaurs (Wukongopteridae) from western Liaoning, China. An. Acad. Bras. Cienc. 82, 1045-1062. (doi:10.1590/S0001-37652010000400024)

7. Upchurch P, Andres B, Butler RJ, Barrett PM. 2015 An analysis of pterosaurian biogeography: implications for the evolutionary history and fossil record quality of the first flying vertebrates. Hist. Biol. 27, 697-717. (doi:10.1080/08912963.2014.939077)

8. Butler RJ, Barrett PM, Nowbath S, Upchurch P. 2009 Estimating the effects of sampling biases on pterosaur diversity patterns: implications for hypotheses of bird/pterosaur competitve replacement. Paleobiology 35, 432-446. 
influence of sampling biases, Lagerstätten, and genuine biodiversity signals. Palaeogeogr. Palaeoclimatol. Palaeoecol. 372, 78-87.

10. Dean Christopher D, Mannion PD, Butler RJ. 2016 Preservational bias controls the fossil record of pterosaurs. Palaeontology 59, 225-247.

11. Wellnhofer P. 1991 The Illustrated Encyclopedia of Pterosaurs. First Edit. Crescent Books.

12. Sullivan C, Wang Y, Hone DWE, Wang Y, Xu X, Zhang F. 2014 The vertebrates of the Jurassic Daohugou Biota of northeastern China. J. Vertebr. Paleontol. 34, 243-280. (doi:10.1080/02724634.2013.787316)

13. Unwin DM. 2001 An overview of the pterosaur assemblage from the Cambridge Greensand (Cretaceous) of Eastern England. Foss. Rec. 4, 189221.

14. Zhou Z, Wang Y. 2010 Vertebrate diversity of the Jehol Biota as compared with other lagerstätten. Sci. China Earth Sci. 53, 1894-1907. (doi:10.1007/s11430-010-4094-9)

15. O'Sullivan M, Martill D. 2018 Pterosauria of the Great Oolite Group (Middle Jurassic, Bathonian) of Oxfordshire and Gloucestershire, England. Acta Palaeontol. Pol. 63. (doi:10.4202/app.00490.2018)

16. Liu Y-Q, Kuang H-W, Jiang X-J, Peng N, Xu H, Sun H-Y. 2012 Timing of the earliest known feathered dinosaurs and transitional pterosaurs older than the Jehol Biota. Palaeogeogr. Palaeoclimatol. Palaeoecol. 323-325, 1-12. (doi:10.1016/J.PALAEO.2012.01.017)

17. Barrett PM. 2006 A sauropod dinosaur tooth from the Middle Jurassic of Skye, 
18. Anquetin J, Barrett PM, Jones ME., Moore-Fay S, Evans SE. 2009 A new stem turtle from the Middle Jurassic of Scotland: new insights into the evolution and palaeoecology of basal turtles. Proc. R. Soc. B Biol. Sci. 276, 879-886. (doi:10.1098/rspb.2008.1429)

19. Panciroli E, Benson RBJ, Walsh S, Butler RJ, Castro TA, Jones MEH, Evans

SE. 2020 Diverse vertebrate assemblage of the Kilmaluag Formation (Bathonian, Middle Jurassic) of Skye, Scotland. Earth Environ. Sci. Trans. $R$. Soc. Edinburgh 111, 135-156.

20. Andres B, Clark J, Xu X. 2014 The earliest pterodactyloid and the origin of the group. Curr. Biol. 24, 1011-1016.

21. Codorniú L, Carabajal AP, Pol D, Unwin D, Rauhut OWM. 2016 A Jurassic pterosaur from Patagonia and the origin of the pterodactyloid neurocranium. PeerJ 4, e2311.

22. Witton MP, O'Sullivan M, Martill DM. 2015 The relationships of Cuspicephalus scarfi Martill and Etches, 2013 and Normannognathus wellnhoferi Buffetaut et al., 1998 to other monofenestratan pterosaurs. Contrib. to Zool. 84, 115-127.

23. Lü J. 2009 A New Non-Pterodactyloid Pterosaur from Qinglong County, Hebei Province of China. Acta Geol. Sin. 83, 189-199. (doi:10.1111/j.1755$6724.2009 .00062 . x)$

24. Lü J, Xu L, Chang H, Zhang X. 2011 A New Darwinopterid Pterosaur from the Middle Jurassic of Western Liaoning, Northeastern China and its Ecological Implications. Acta Geol. Sin. - English Ed. 85, 507-514. (doi:10.1111/j.1755$6724.2011 .00444 . x)$ 
Mongolia. Chinese Sci. Bull. 50, 2369-2376. (doi:10.1007/bf03183749)

26. Liu Y, Liu Y, Ji S, Yang Z. 2006 U-Pb zircon age for the Daohugou Biota at Ningcheng of Inner Mongolia and comments on related issues. Chinese Sci. Bull. 51, 2634-2644. (doi:10.1007/s11434-006-2165-2)

27. Liu Y, Liu Y, Zhang H. 2010 LA-ICPMS Zircon U-Pb Dating in the Jurassic Daohugou Beds and Correlative Strata in Ningcheng of Inner Mongolia. Acta Geol. Sin. - English Ed. 80, 733-742. (doi:10.1111/j.1755-

6724.2006.tb00296.x)

28. Zhang H, Wang M, Liu X. 2008 Constraints on the upper boundary age of the Tiaojishan Formation volcanic rocks in West Liaoning-North Hebei by LA-ICPMS dating. Chinese Sci. Bull. 53, 3574-3584. (doi:10.1007/s11434-008-02874)

29. Gao H-L, Zhao Y, Zhang S-H, Liu J, Ye H, Wang G-C, Liu J-M. 2019 Ages of Jurassic volcano-sedimentary strata in the Yanshan Fold-and-Thrust Belt and their implications for the coal-bearing strata of northern China. Int. Geol. Rev. 61, 956-971. (doi:10.1080/00206814.2018.1481459)

30. Tischlinger H, Frey E. 2014 A new pterosaur with mosaic characters of basal and pterodactyloid Pterosauria from the Upper Kimmeridgian of Painten (Upper Palatinate, Germany). Archaeopteryx 31, 1-13.

31. Buffetaut E, Jeffery P. 2012 A ctenochasmatid pterosaur from the Stonesfield Slate (Bathonian, Middle Jurassic) of Oxfordshire, England. Geol. Mag. 149, 552-556. (doi:10.1017/S0016756811001154)

32. W B. 1829 On the discovery of a new species of Pterodactyle in the Lias at Lyme Regis. Trans. Geol. Soc. London 3, 217-222.

33. Clark NDL, Gavin P. 2016 New bathonian (Middle Jurassic) sauropod remains 
from the valtos formation, Isle of Skye, Scotland. Scottish J. Geol. 52, 71-75. (doi:10.1144/sjg2015-010)

341 34. Wills S, Barrett PM, Walker A. 2014 New dinosaur and crocodylomorph material from the middle Jurassic (Bathonian) Kilmaluag formation, Skye, Scotland. Scottish J. Geol. 50, 183-190. (doi:10.1144/sjg2014-005)

35. Brusatte SL et al. 2015 Ichthyosaurs from the jurassic of skye, scotland.

Scottish J. Geol. 51, 43-55. (doi:10.1144/sjg2014-018)

36. Panciroli E, Benson RBJ, Luo ZX. 2019 The mandible and dentition of 
bioRxiv preprint doi: https://doi.org/10.1101/2022.02.14.480264; this version posted February 16, 2022. The copyright holder for this

preprint (which was not certified by peer review) is the author/funder. All rights reserved. No reuse allowed without permission. 